\title{
Memahami Perilaku Penerimaan Mobile Payment di Kalangan Muda (Mahasiswa) Menggunakan Pengembangan Model IMMPA
}

\author{
Dewi Widyawati ${ }^{1}$, Wing Wahyu Winarno ${ }^{2}$ \\ ${ }^{1}$ Fakultas Teknologi Industri, Jurusan Teknik Informatika, Universitas Islam Indonesia, Yogyakarta, Indonesia \\ ${ }^{2}$ Sekolah Tinggi Ilmu Ekonomi YKPN Yogyakarta, Indonesia \\ Email: ${ }^{1} 16917206 @$ students.uii.ac.id, ${ }^{2}$ wingwahyuwinarno@gmail.com
}

\begin{abstract}
Abstrak-Sejak munculnya perdagangan digital dalam bentuk m-commerce, layanan mobile payment mulai mendapatkan perhatian global. Mudahnya akses ke layanan mobile payment, manfaat yang ditawarkan, dan kejelasan regulasi yang mengaturnya ternyata belum sepenuhnya menarik minat semua masyarakat Indonesia untuk menggunakannya. Mengubah perilaku bertransaksi ke mobile payment sejalan dengan akses ekonomi digital, yang berpotensi akan meningkatkan pertumbuhan ekonomi suatu negara bahkan sampai ke level makro. Studi ini akan mengindentifikasi determinan penerimaan dan penggunaan aktual dari layanan mobile payment pada kalangan muda. Pengguna yang lebih muda lebih cenderung untuk menerima dan mengadopsi teknologi dan layanan teknologi terutama kalangan muda yang berada di linkungan kampus, sehingga mahasiswa akan diambil sebagai responden pada penelitian ini. Studi ini menggunakan Integrated Model on Mobile Payment Acceptance (IMMPA) oleh Di Pietro et al. (2015) dan menambahkan satu konstruk yang relevan dengan faktor yang mempengaruhi penggunaan layanan mobile payment yaitu Trust. Konstruk baru lainnya yang dikembangkan dari model IMMPA adalah Perceived Security yang dihubungkan dengan Trust. Kerangka teoritis diuji menggunakan Structural Equation Model (SEM). Temuan penelitian menunjukkan bahwa, Intention To Use berpengaruh kuat terhadap User's Behavior, sementara Intention to Use dipengaruhi kuat oleh Trust. Perceived security berpengaruh terhadap Trust. Ease of Use berpengaruh terhadap Usefulness.
\end{abstract}

Kata Kunci: Mobile Payment, IMMPA, User's Behavior, Trust, SEM

\begin{abstract}
Since the emerge of digital commerce in the form of m-commerce, mobile payment services have started to get global attention. Easy access to mobile payment services, the benefits offered, and the clarity of the regulations that govern them, have not yet fully attracted the interest of all Indonesian people to use them. Changing the behavior of transactions to mobile payments in line with access to the digital economy, which has the potential to increase a country's economic growth even to the macro level. This study will identify the determinants of actual acceptance and use of mobile payment services among young people. Younger users are more likely to receive and adopt technology and technology services, especially young people who are in the campus environment, so students will be taken as respondents in this study. This study uses the Integrated Model on Mobile Payment Acceptance (IMMPA) by Di Pietro et al. (2015) and adding one construct that is relevant to the factors that influence the use of mobile payment services, namely Trust. Another new construct developed from the IMMPA model is Perceived Security which is linked to Trust. The theoretical framework was tested using the Structural Equation Model (SEM). The research findings show that Intention to Use strongly influences User's Behavior, while Intention to Use is strongly influenced by Trust. Perceived security influences Trust. Ease of Use affects Usefulness
\end{abstract}

Keywords: Mobile Payment, IMMPA, User's Behavior, Trust, SEM

\section{PENDAhuluan}

Sejak munculnya perdagangan digital dalam bentuk $m$-commerce, layanan mobile payment mulai mendapatkan perhatian global [1]. Banyaknya masyarakat yang dapat mengakses internet dan smartphone menyebabkan munculnya berbagai peluang bisnis salah satunya dalam hal keuangan. Sebagai inovasi yang mengganggu (disruptive innovation), gelombang financial technologi (Fintech) tampaknya tidak bisa dihindarkan, dalam rangka merespon tantangan revolusi industri 4.0. Hadirnya layanan ini mengubah cara masyarakat dalam berkegiatan finansial, bermula dari kebutuhan manusia untuk berbelanja dengan nyaman tanpa harus meninggalkan rumah.

Layanan mobile payment mengacu pada penggunaan perangkat bergerak seperti ponsel untuk mentransfer dana dari satu pihak (pembayar) ke penerima lainnya secara elektronik dengan cara langsung atau melalui perantara. Teknologi pada mobile payment pada awalnya berbasis SMS, lalu teknologi koneksinya berkembang menjadi contactless seperti Bluetooth, Infrared (IR), Near Field Communication (NFC) dan Radio Frequency ID [2]. Memanfaatkan media seperti smartcard dan ponsel, transaksi mobile payment ini menjadi lebih mudah karena cukup menempelkan ponsel atau kartu ke mesin pembaca sebagai bagian dari komunikasi mesin ke mesin [3].

Di masa sekarang ini mobile payment (MP/ pembayaran seluler) yang lebih populer digunakan dalam bentuk aplikasi yang diinstal pada smartphone. Layanan ini diharuskan untuk menautkan akun pembayaran seluler dengan rekening bank dan membuat kredensial masuk. Layanan ini memungkinkan konsumen untuk melakukan transaksi seperti membayar barang, jasa, maupun tagihan, mengirim dan menerima, mengisi saldo akun mereka atau mengisi saldo akun orang lain hanya menggunakan perangkat seluler mereka.

Di Indonesia sendiri layanan ini banyak bermunculan dan mulai bervariasi yang memperlihatkan karakteristik yang berbeda dari masing-masing layanan. Ada yang menyatu dengan layanan transportasi online, ada yang berafiliasi dengan layanan e-commerce atau keduanya (transportasi online dan e-commerce), dan ada juga yang berafiliasi dengan layanan BUMN. Pemerintah menggalakkan penggunaan uang digital melalui program Gerakan Nasional Non Tunai /GNNT sejak tahun 2014 [4], dan mengeluarkan regulasi yang mengatur uang elektronik untuk mendukung program tersebut. Ditambah lagi saat ini bank juga bersaing meningkatkan pangsa 
pasar mereka dengan mulai merajut kolaborasi, dan mengakuisisi Fintech. Oleh karena itu, masyarakat seolah diajak untuk beralih ke pembayaran digital yang sebelumnya mengandalkan cara konvensional ke pembayaran mobile payment sebagai pembayaran utama mereka.

Mudahnya mengakses ke layanan mobile payment, manfaat yang ditawarkan, dan kejelasan regulasi yang mengaturnya, ternyata hal tersebut belum sepenuhnya menarik minat semua masyarakat Indonesia untuk menggunakan layanan ini. Sebuah survei yang dilakukan oleh PricewaterhouseCoopers (PwC) [5], membahas salah satunya yaitu pertumbuhan terbesar mobile payment global, survei tersebut memperlihatkan dari 21.480 responden global, hanya $47 \%$ responden Indonesia saat ini yang menggunakan pembayaran bergerak untuk bertransaksi pada kuarter pertama tahun 2019. Survei tersebut memperlihatkan penggunaan mobile payment yang berbasis aplikasi. Meskipun jumlah orang Indonesia yang melakukan pembayaran seluler di peringkat kelima, ternyata negara ini masih kalah dengan pengguna pembayaran seluler di Vietnam. Sementara itu, terkait pola belanja masyarakat, PwC mencatat bahwa kebiasaan masyarakat untuk berbelanja langsung di toko masih terus tumbuh. Berdasarkan fakta tersebut, menjadi menarik bagi penulis untuk mengungkap perilaku pengguna dalam penerimaan dan penggunaan aktual pada layanan mobile payment.

Banyak studi penelitian terkait adopsi suatu layanan, ditemukan fakta bahwa penelitian-penelitian tersebut mengarah pada dua tujuan utama. Pertama beberapa studi mengeksplorasi niat untuk menggunakan sebuah produk inovasi seperti pada penelitian [1], [6]-[8], dan studi yang lain mengeksplorasi perilaku penggunaan seperti pada penelitian [9]-[11]. Antara niat dan perilaku pada dasarnya berbeda. Menurut teori perilaku terencana, kinerja suatu perilaku adalah fungsi bersama dari niat dan kontrol perilaku yang dirasakan. Kinerja sebagian besar perilaku tergantung, setidaknya sampai tingkat tertentu, pada faktor-faktor non-motivasi seperti ketersediaan peluang dan sumber daya yang diperlukan seperti waktu, uang, keterampilan, dan kerjasama orang lain [12]. Dengan demikian, penelitian ini akan menilai perilaku pengguna dalam hal kesiapan menggunakan sekaligus perilaku evaluasi individu terhadap penggunaan mobile payment.

Dalam menganalisis faktor-faktor perilaku penggunaan layanan mobile payment, penelitian ini akan mengeksplorasi Integrated Model on Mobile Payment (IMMPA) yang dibuat oleh Di Pietro et al., (2015) [13] untuk menganalisis perilaku penerimaan khususnya pada layanan mobile payment. Memperluas model tersebut, penelitian ini menambahkan konstruk kepercayaan (trust) sebagai salah satu konstruk yang penting dalam setiap kegiatan yang berkaitan dengan pembayaran. Model tersebut akan diuji pada perilaku adopsi mobile payment di kalangan muda.

Sebagaimana dinyatakan oleh berbagai peneliti bahwa, pengguna yang lebih muda lebih cenderung untuk menerima teknologi dan layanan teknologi [14]. Termasuk kategori kalangan muda adalah generasi millenial atau kadang disebut dengan generasi $\mathrm{Y}$ atau Echo Boomers. Mereka adalah sekelompok orang yang lahir setelah generasi X, yaitu orang yang lahir pada kisaran tahun 1980 - 1999. Ini berarti yang termasuk generasi millennial adalah masyarakat yang saat ini berumur 17-37 tahun. Mereka memiliki keingintahuan yang lebih akan hal-hal yang baru sehingga mereka tidak ragu untuk mencobanya [15]. Memahami perilaku adopsi mobile payment dari penelitian ini diharapkan lembaga keuangan, pihak ketiga yang tepercaya, dan penyedia layanan pembayaran, dapat mengambil manfaat dari peningkatan pemahaman tentang faktor-faktor yang mendasari perilaku pengguna mobile payment.

\section{METODE PENELITIAN}

\subsection{Pengembangan Model IMMPA}

Penelitian ini akan menggunakan Integrated Model On Mobile Payment (IMMPA) diusulkan oleh Di Pietro et al., (2015) [13], penelitiannya menyoroti kesenjangan terkait kemampuan model penerimaan teknologi yang sudah ada sebelumnya yaitu TAM [16], DOI [17] dan UTAUT [18]. Uji coba model tersebut telah dilakukan dalam konteks penerimaan pembayaran mobile ticketing di sektor transportasi umum. Beberapa dimensi gabungan diusulkan karena memiliki kesamaan di antara tiga model telah disebutkan. Di Pietro menggabungkan dimensi Relative Advantage dalam DOI mirip dengan dimensi Usefulness yang dipersepsikan dalam TAM, dan dimensi Complexity dalam DOI menyamakan dimensi Ease Of Use yang dipersepsikan dalam TAM. Karena model-model yang telah dibuat berdasarkan teori-teori yang telah disebutkan sebelumnya relatif cukup lampau sehingga perlu disesuaikan dengan masa sekarang dan perlu untuk mengetahui pengaruh model IMMPA tersebut pada konteks pengguna di Indonesia.

Selain menilai konstruk pada IMMPA diatas, yang juga penting dalam analisis penerimaan mobile payment adalah perlu adanya trust (kepercayaan) apalagi pada hal-hal yang melibatkan transaksi uang keercayaan konsumen dinilai penting. Trust (kepercayaan) juga telah menjadi fokus adopsi mobile payment yang selalu berulang diantaranya pada penelitian [6], [8], [9], [19]-[21]. Kepercayaan adalah penentu penting yang mempengaruhi niat konsumen menggunakan internet untuk melakukan transaksi online dan secara umum kurangnya kepercayaan konsumen dapat membuat hambatan untuk mengadopsi layanan teknologi [22]. Pada penelitian ini akan menghubungkan variabel kepercayaan trust dengan variabel security pada model IMMPA. Fan et al., (2017) [19], menilai bahwa perceived security dan trust dapat secara positif memengaruhi sikap pengguna 
ISSN 2614-5278 (media cetak), ISSN 2548-8368 (media online)

Available Online at https://ejurnal.stmik-budidarma.ac.id/index.php/mib

DOI 10.30865/mib.v4i2.2068

pembayaran seluler. Ketika orang memiliki persepsi yang lebih tinggi tentang security dan trust, mereka lebih cenderung memiliki sikap positif terhadap pembayaran seluler.

Berdasarkan dua model penelitian diatas, penelitian ini menambahkan variabel trust yang dipengaruhi oleh perceived security dari model Fan et al., 2017, serta pengaruh trust langsung pada intention to use. Penelitian ini mengusulkan gambaran pengembangan model IMMPA yang akan digunakan seperti pada gambar 1 .

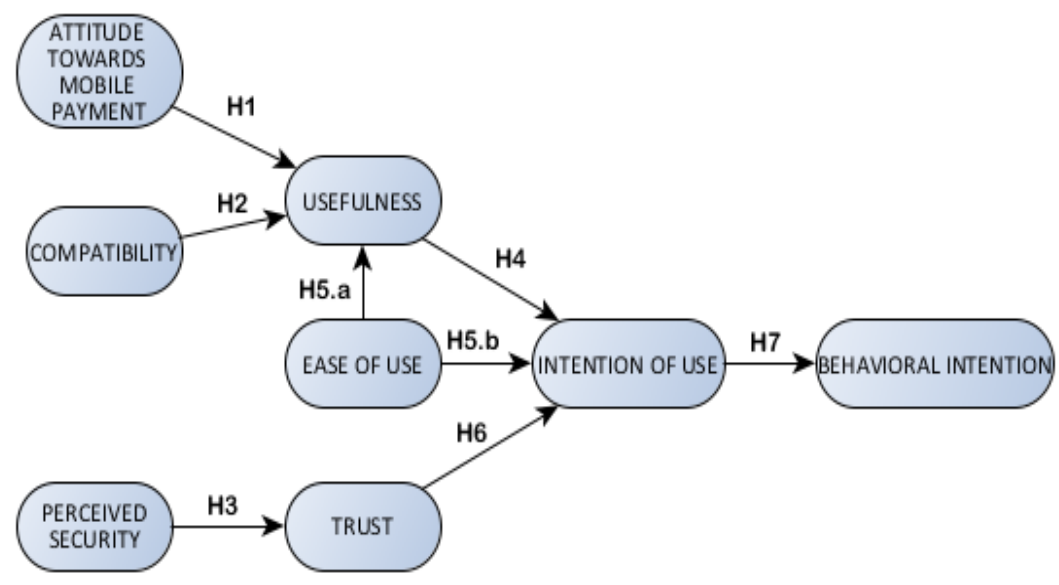

Gambar 1. Usulan Model Pengembangan IMMPA

Indikator dan desain penelitian pada penelitian ini diadopsi dari indikator penelitian terdahulu yang relevan dengan konteks penelitian dari hasil studi pustaka, sehinga disajikan pada tabel 1.

Tabel 1. Desain Indikator Peneltian

\begin{tabular}{|c|c|c|c|}
\hline Variabel & Kode & Indikator & \\
\hline \multirow[t]{5}{*}{ Usefulness (U) } & U1 & Menggunakan Mobile payment dapat memenuhi kebutuhan pembayaran saya. & [13] \\
\hline & $\mathrm{U} 2$ & Menggunakan m-payment akan memudahkan saya untuk berbelanja & [1] \\
\hline & U3 & Menggunakan m-payment meningkatkan produktivitas saya. & [7] \\
\hline & U4 & $\begin{array}{l}\text { Saya pikir diskon dan promosi untuk pembelian barang dan jasa, Sangat berguna } \\
\text { bagi saya. }\end{array}$ & [13]. \\
\hline & U5 & Secara keseluruhan, layanan m-payment bermanfaat bagi saya. & [24] \\
\hline \multirow[t]{4}{*}{$\begin{array}{l}\text { Compatibility } \\
\text { (CO) }\end{array}$} & $\mathrm{CO} 1$ & $\begin{array}{l}\text { Saya percaya bahwa menggunakan metode } m \text {-payment kompatibel dengan cara saya } \\
\text { biasa berbelanja. }\end{array}$ & [1] \\
\hline & $\mathrm{CO} 2$ & Proses transfer uang melalui m-payment selalu akurat dan stabil & [19] \\
\hline & $\mathrm{CO} 3$ & Saya percaya bahwa menggunakan m-payment tidak akan merepotkan. & [1] \\
\hline & $\mathrm{CO} 4$ & $\begin{array}{l}\text { Dibandingkan dengan metode pembayaran tradisional, saya percaya bahwa metode } \\
\text { m-payment lebih nyaman. }\end{array}$ & [1] \\
\hline \multirow{4}{*}{$\begin{array}{l}\text { Ease of Use } \\
\text { (EU) }\end{array}$} & EU1 & Ketika saya menggunakan m-payment, prosesnya akan jelas dan dapat dimengerti. & [6] \\
\hline & EU2 & Menggunakan m-payment akan meningkatkan kecepatan transaksi. & [1] \\
\hline & EU3 & Antarmuka pengguna pada perangkat $m$-payment ramah dan mudah dimengerti & [24] \\
\hline & EU4 & Mudah bagi saya untuk menjadi terampil dalam menggunakan m-payment. & [24] \\
\hline \multirow[t]{3}{*}{ Trust (TR1) } & TR1 & Saya percaya bahwa pihak m-payment akan menawarkan layanan yang aman. & [21] \\
\hline & TR2 & $\begin{array}{l}\text { Dibandingkan dengan metode pembayaran tradisional, saya percaya bahwa } \\
\text { menggunakan m-payment lebih berisiko. }\end{array}$ & {$[19]$} \\
\hline & TR3 & Saya percaya informasi yang diberikan selama proses MP & [20] \\
\hline \multirow[t]{3}{*}{$\begin{array}{l}\text { Attitude } \\
\text { (ATT) }\end{array}$} & ATT1 & $\begin{array}{l}\text { Saya percaya bahwa menggunakan metode m-payment akan meningkatkan citra } \\
\text { gaya hidup saya. }\end{array}$ & [1] \\
\hline & ATT2 & Menggunakan layanan Mobile payment adalah pengalaman yang menyenangkan. & [1] \\
\hline & ATT3 & $\begin{array}{l}\text { Menggunaan aplikasi berbasis internet di ponsel sudah menjadi kebiasaan bagi } \\
\text { saya. }\end{array}$ & {$[25]$} \\
\hline \multirow{3}{*}{$\begin{array}{l}\text { Perceived } \\
\text { Security (PS) }\end{array}$} & PS1 & Saya percaya bahwa metode m-payment akan memasukkan keamanan yang cukup. & [1], [7] \\
\hline & PS2 & $\begin{array}{l}\text { Saya percaya bahwa metode m-payment akan memiliki kontrol keamanan untuk } \\
\text { mencegah penipuan. }\end{array}$ & [19] \\
\hline & PS3 & $\begin{array}{l}\text { Saya merasa aman memasukkan detail informasi akun saya dalam aplikasi } \\
\text { pembayaran. }\end{array}$ & [13] \\
\hline \multirow[t]{4}{*}{$\begin{array}{l}\text { Intention to } \\
\text { Use (IU) }\end{array}$} & IU1 & $\begin{array}{l}\text { Saya memiliki peralatan (ponsel, App, WiFi), pengetahuan, dan skill yang } \\
\text { diperlukan untuk menggunakan m-payment. }\end{array}$ & {$[25]$} \\
\hline & IU3 & Menggunakan m-payment adalah ide yang bijaksana. & [1] \\
\hline & IU3 & Saya tertarik menggunakan layanan mobile payment & {$[26]$} \\
\hline & UB1 & Menggunakan layanan pembayaran seluler adalah ide yang bagus. & [1] \\
\hline
\end{tabular}



DOI 10.30865/mib.v4i2.2068

\begin{tabular}{llll}
\hline \multicolumn{1}{c}{ Variabel } & Kode & \multicolumn{2}{c}{ Indikator } \\
\hline User's & UB2 & Saya pikir kedepannya akan menggunakan m-payment seterusnya. \\
\cline { 2 - 5 } Behavior (UB) & UB3 & $\begin{array}{l}\text { Merasakan manfaat yang saya rasakan, saya akan merekomendasikan mobile } \\
\text { payment ke orang dekat. }\end{array}$ & [27]
\end{tabular}

\subsection{Pengumpulan Data}

Pengumpulan data pada penelitian dilakukan melalui pembagian kuesioner. Strategi penyebaran kuesioner dilakukan di lingkungan kampus di Yogyakarta. Dengan melakukan observasi lapangan dan sebagian kuesioner disebarkan secara daring melalui Google Form. Setelah seluruh data penelitian melalui pembagian kuesioner telah terkumpul dengan lengkap dan sah selanjutnya dilakukan pengolahan data.

Penentuan jumlah sampel minimal pada penelitian ini mengacu pada metode (Hair et al., 1998) dalam yang menyatakan bahwa banyaknya sampel sebagai responden harus disesuaikan dengan banyaknya indikator pertanyaan yang digunakan pada kuesioner. Dengan asumsi $\mathrm{n}$ (observed variable /indikator) x 5 sampai dengan $\mathrm{n}$ $\mathrm{x} 10$ observed variable (indikator). Dengan demikian didapatkan 125-150 responden.

\subsection{Analisis Structural Equation Model (SEM)}

Metode Structural Equation Model (SEM) merupakan metode analisis kelanjutan dari analisis jalur (path analysis) dan regresi berganda (multiple regression) yang sama-sama merupakan bentuk analisis multivariat Data yang telah terkumpul melalui kuesioner akan diolah lebih lanjut melalui uji model fit apakah model memenuhi kecocokan dengan data dan selanjutnya dilakukan uji hipotesis.Langkah analisis faktor konfirmatori pada SEM dapat dilihat pada Gambar 2.2.

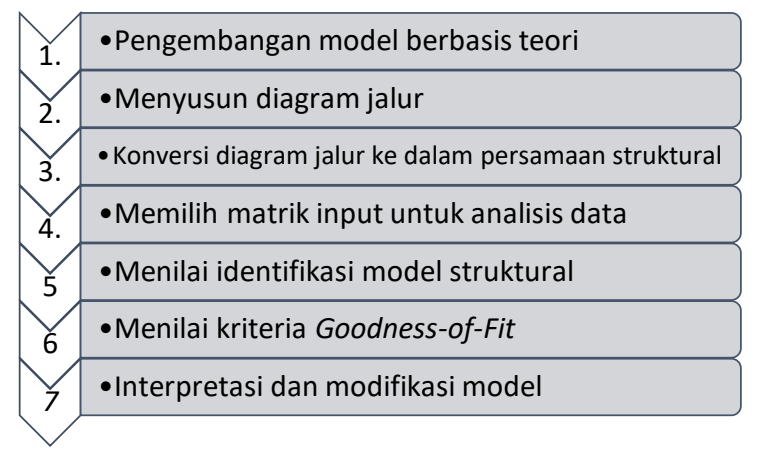

Gambar 2. Langkah-langkah analisis SEM

\section{HASIL DAN PEMBAHASAN}

\subsection{Karakteristik Responden}

Hasil dan pembahasan meliputi: karakteristik responden, proses pengumpulan data melibatkan 140 orang responden baik yang menggunakan, belum menggunakan, ataupun yang belum menginstal aplikasi mobile payment. Sebesar $99,2 \%$ menyatakan menginstal aplikasi, 97,6\% menyatakan menggunakan, hanya satu orang tidak menginstal, dan tiga orang tidak mengunakan. Responden yang berpartisipasi pada penelitian ini terbanyak dari kalangan mahasiswa, lebih dominan jenis kelamin perempuan yaitu sebanyak (77\%) dari total responden, disusul dengan laki-laki 23\%. Dimana karakteristik umur responden adalah 17-21 tahun sebanyak 74 (58,7\%), dan 22-25 tahun sebanyak 24 (19\%). Frekuensi penggunaan aplikasi mobile payment paling banyak menjawab biasa menggunakan (seminggu 2-3 kali). Secara ringkas gambaran umum responden disajikan pada tabel 2.

Tabel 2. Gambaran umum responden

\begin{tabular}{crr}
\hline \multicolumn{1}{c}{ Item } & Frekuensi & \% \\
\hline Jenis Kelamin & & \\
Laki-laki & 34 & $24,3 \%$ \\
Perempuan & 106 & $75,7 \%$ \\
Umur & & \\
$17-21$ & 82 & $58,6 \%$ \\
$22-25$ & 30 & $21,4 \%$ \\
$26-30$ & 21 & $15 \%$ \\
$31-37$ & 7 & $5 \%$ \\
Pendidikan & & \\
< Diploma & & \\
\hline
\end{tabular}


ISSN 2614-5278 (media cetak), ISSN 2548-8368 (media online)

Available Online at https://ejurnal.stmik-budidarma.ac.id/index.php/mib DOI $10.30865 /$ mib.v4i2.2068

\begin{tabular}{lrr}
\hline Diploma & 4 & $29 \%$ \\
$\quad$ Sarjana & 121 & $86,4 \%$ \\
$\quad$ Pascasarjana & 15 & $10,7 \%$ \\
Frekuensi penggunaan aplikasi & & \\
mobile payment & & \\
- Sering (dalam sehari-hari) & 35 & $27,8 \%$ \\
- Biasa (2-3 kali seminggu) & 54 & $42,9 \%$ \\
- Kadang (1 kali seminggu) & 32 & $25,4 \%$ \\
- Jarang (tidak pernah) & 5 & $4 \%$ \\
\hline
\end{tabular}

\subsection{Analisis Faktor Konfirmatori (Confirmatory Faktor Analysis)}

Hasil kuesioner berupa data, akan disimpan dalam format Excel atau SPSS dan langsung digunakan sebagai data mentah untuk analisa dengan software AMOS 23.0. AMOS (Analysis of Moment Structure) dikembangkan oleh James L. Arbuckle, merupakan program komputer yang dapat digunakan untuk membuat model persamaan struktural, disamping beberapa program lainnya AMOS lebih userfriendly namun juga powerfull, sehingga saat ini merupakan program yang paling banyak digunakan untuk mengolah berbagai model riset yang menggunakan SEM.

Pada langkah analisis SEM, langkah pertama dilakukan pengembangan model berbasis teori. Hal ini dapat dilihat pada Gambar 2.1 yang telah dibahas sebelumnya.

Langkah kedua, dilakukan penyusunan diagram jalur model. Variabel-variabel laten atau konstruk yang digunakan pada model penelitian ini terdiri dari 8 konstruk dengan jumlah seluruh dimensi berjumlah 28 . Karakteristik dasar penggunaan SEM dalam pembentukan persamaan strukturalnya adalah harus melibatkan dua jenis variabel, yaitu variabel observasi dan laten. Variabel observasi mempunyai data seperti data angka atau skala penilaian yang diambil dari kuesioner. Sedangkan variabel laten adalah variabel yang secara tidak langsung teramati. Pada program Amos, setiap variabel laten yaitu ATT (Attitude), CO (Compatibility), dan PS (Perceived Security) juga ikut dihubungkan agar proses data dapat dijalankan. Hal ini menyebabkan kebutuhan jumlah data harus ditambah. Pada tahap pertama pengujian diperoleh nilai probability model yang belum memenuhi, maka dilakukan penambahan data menjadi sebanyak 140 yang siap dianalisis ulang.

Langkah ketiga, diagram jalur diatas akan dikonversi ke persamaan struktural. Hasil analisis faktor konfirmatori dari masing-masing konstruk pada Gambar 3 merepresentasikan bahwa data yang telah dikumpulkan memiliki kecocokan dengan konstruk, terbukti bahwa semua konstruk memiliki nilai probability $\geq 0,05$. Hal ini berarti pengujian masing-masing konstruk baik, dan pengujian seluruh model dapat dilakukan,
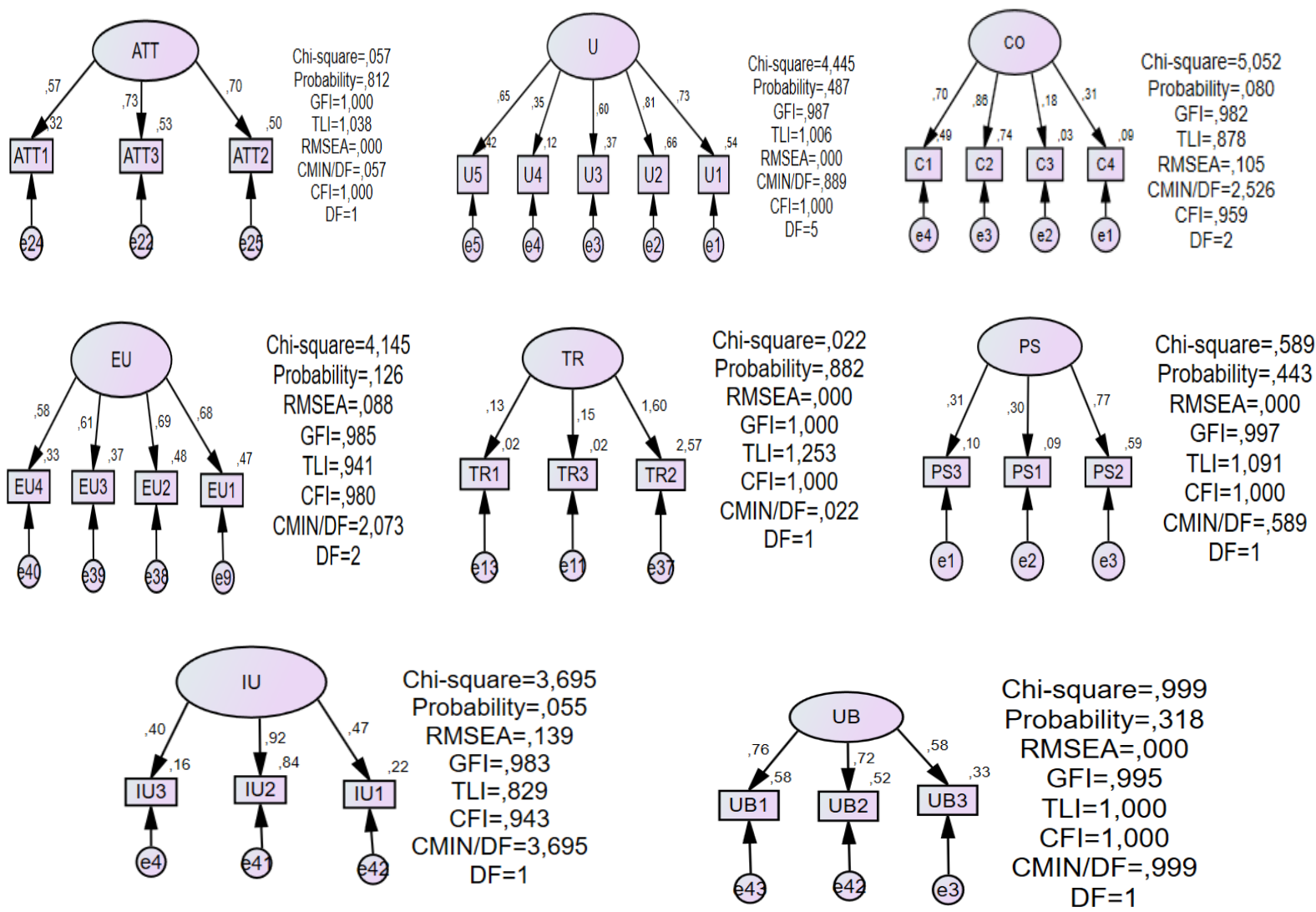

Gambar 3. Analisis Faktor Konfirmatori Masing-masing Konstruk 
JURNAL MEDIA INFORMATIKA BUDIDARMA

Volume 4, Nomor 2, April 2020, Page 453-460

ISSN 2614-5278 (media cetak), ISSN 2548-8368 (media online)

Available Online at https://ejurnal.stmik-budidarma.ac.id/index.php/mib

DOI 10.30865/mib.v4i2.2068

Langkah keempat, untuk analisis kecocokan model, dibuat diagram persamaan struktural model secara keseluruhan seperti pada Gambar 4 Dipilih matriks input stardardized estimate (untuk melihat nilai standar hubungan kausalitas), squared multiple corelations (untuk melihat besar pengaruh variabel X ke Y), metode estimasi yang dipilih pada penelitian ini adalah maximum likelihood estimates (MLE), dan lain-lain.

Langkah kelima, setelah dilakukan pengujian, ternyata ada beberapa indikator yang dinyatakan kurang layak mewakili variabel latennya. Indikator-indikator yang kurang layak tersebut adalah ATT2 yang mewakili variabel Attitude tentang "pengalaman yang menyenangkan dari mobile payment", sehingga tidak disertakan pada pengujian model berikutnya.

Langkah keenam, dilakukan pengujian model dengan melihat nilai terukur apakah memenuhi cut of value yang telah ditetapkan berdasarkan studi literatur.

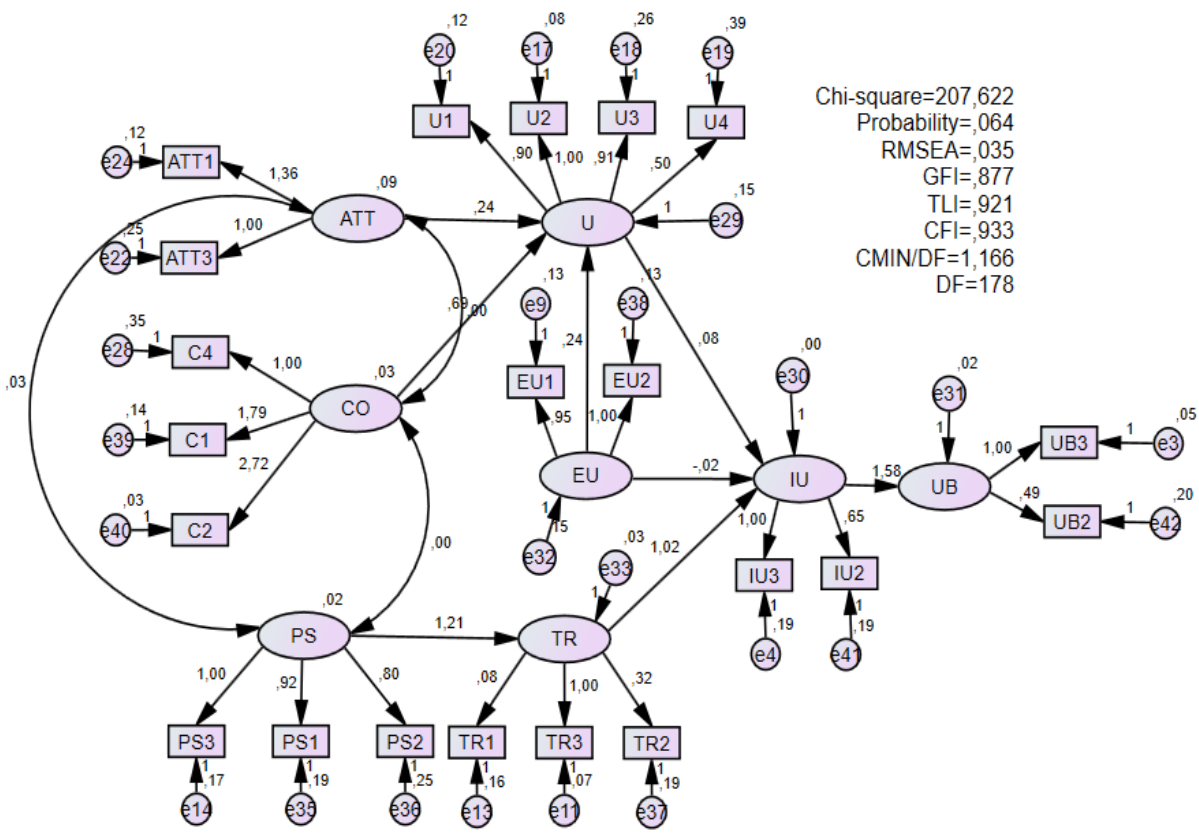

Gambar 4. Diagram Jalur ke Persamaan Struktural

Langkah ketujuh, SEM dikembangkan dan dianalisis untuk menyelidiki apakah model teoritis yang diusulkan konsisten dengan data yang dikumpulkan. Setelah terlihat bahwa model hanya menyertakan indikatorindikator yang memiliki kesesuian dengan model, maka dilakukan pengujian ulang goodness of fit sampai didapatkan nilai yang memenuhi cut of value. Hasil akhir CFA full model dan SEM diperoleh pada tabel 3.

Tabel 3. Hasil Uji Kesesuaian Model

\begin{tabular}{lrrl}
\hline Goodness of Fit & Cut of Value & Nilai & Keterangan \\
\hline $\left.\mathrm{x}^{2}\right)$ Chi Square & Diharapkan & 207,622 & Baik \\
& kecil & & \\
Probability & $\geq 0,05$ & 0,064 & Baik \\
RMSEA & $\leq 0,08$ & 0,035 & Baik \\
GFI & $0-1$ & 0,877 & Baik \\
CMIN/DF & $\leq 2,0$ & 1,16 & Baik \\
TLI & $\geq 0,95$ & 0,921 & Baik \\
CFI & $0-1$ & 0,933 & Baik \\
\hline
\end{tabular}

Berdasarkan hasil olah data di atas menunjukan bahwa nilai probability pengujian goodness of fit sebesar 0,064, dengan kirteria semua aspek hasil evaluasi baik, CFI =0,933; TLI =0,921; RMSEA = 0,035; Chi-Square = 207,622 dengan 178 degree of freedom (DF). Setelah memenuhi nilai signifikansi/ probability, analisis selanjutnya dapat dilanjutkan. Penelitian Di Pietro et al., (2015) sebelumnya yang menggunakan model tersebut memperoleh hasil nilai kelayakan model probability $=0.000, \mathrm{Df}=338, \mathrm{CFI}=0,907, \mathrm{TLI}=0,896, \mathrm{RMSEA}=0,061$ dengan sampel data 200

\subsection{Uji Hipotesis}

Setelah mendapatkan model yang fit, analisis regresi hubungan struktural antara variabel X ke Y dapat dilakukan. Uji Hipotesis dilakukan otomatis menggunakan sistem Amos 23.0. Pada pengamatan Standardized Regression Weight diperoleh hasil uji hipotesis pada tabel 4. 
Tabel 4. Hasil Uji Hipotesis

\begin{tabular}{lllrllll}
\hline & & & Estimate & S.E. & C.R. & P & Kesimpulan \\
\hline TR & $<---$ & PS & 1,209 &, 527 & 2,294 &, 022 & Diterima \\
U & $<---$ & EU &, 236 &, 141 & 1,680 &, 093 & Ditolak \\
U & $<---$ & ATT &, 241 &, 159 & 1,514 &, 130 & Ditolak \\
U & $<---$ & CO &, 688 &, 317 & 2,168 &, 030 & Diterima \\
IU & $<---$ & EU &,- 023 &, 063 &,- 371 &, 710 & Ditolak \\
IU & $<---$ & TR & 1,016 &, 279 & 3,645 & $* * *$ & Diterima \\
IU & $<---$ & U &, 077 &, 057 & 1,349 &, 177 & Ditolak \\
UB & $<---$ & IU & 1,578 &, 311 & 5,066 & $* * *$ & Diterima \\
\hline
\end{tabular}

Berdasarkan standar nilai signifikansi $\alpha=5 \%$, atau Critical Ratio $=\leq 1,96$. Berdasarkan hasil pengujian hipotesis diatas, ditemukan bahwa faktor Intention To Use (IU) berpengaruh kuat terhadap User's Behavior (UB), disusul oleh Trust (TR) berpengaruh kuat terhadap Intention To Use (IU) sementara Perceived Security secara signifikan berpengaruh terhadap Trust (TR), dan Compatibility (CO) juga berpengaruh terhadap Usefulness (U). Dengan demikian H3, H5.a, H6, H7 diterima.

Sedangkan faktor Attitude terhadap Usefulness tidak berpengaruh (H1), Usefulness terhadap Intention to use tidak berpengaruh (H4), Ease of Use terhadap Usefulness tidak berpengaruh dengan kuat (H5.a) demikian pulan Ease of Use tidak berpengaruh terhadap Usefulness. Dengan demikian H1, H4, H5.a, H5.b ditolak. Sejalan dengan penelitian yang dilakukan oleh Phonthanukitithaworn (2016) [21], manfaat yang dirasakan ternyata bukan hal yang mempengaruhi niat untuk menggunakan layanan mobile payment. Hal ini diasumsikan terjadi karena manfaat bukanlah dipengaruhi oleh sikap (yang terdiri dari peningkatan citra gaya hidup, pengalaman menyenangkan yang dirasakan, dan kebiasaan berteknologi). Sehingga sikap, bukanlah hal yang mempengaruhi manfaat yang dirasakan melalui layanan ini. Dari sisi kemudahan juga dirasa tidak berpengaruh terhadap niat untuk menggunakan, hal ini diasumsikan karena layanan mungkin kurang dalam hal kecepatan transaksi, dan kejelasan proses, antarmuka layanan yang kurang ramah, sehingga dirasa kurang terampil dalam penggunaan layanan ini, diasumsikan sebagai penyebab seseorang tidak berniat untuk menggunakannya

\section{KESIMPULAN}

Berdasarkan hasil penelitian, maka dapat disimpulkan sebagai berikut:

1. Manfaat yang dirasakan ternyata bukan hal yang mempengaruhi niat untuk menggunakan layanan mobile payment. Hal ini diasumsikan terjadi karena manfaat bukanlah dipengaruhi oleh sikap (yang terdiri dari peningkatan citra gaya hidup, pengalaman menyenangkan yang dirasakan, dan kebiasaan berteknologi). Sikap, bukanlah hal yang mempengaruhi manfaat yang dirasakan melalui layanan ini. Dari sisi kemudahan juga dirasa tidak berpengaruh terhadap niat untuk menggunakan, hal ini diasumsikan karena layanan mungkin kurang dalam hal kecepatan transaksi, kejelasan proses, antarmuka layanan yang kurang ramah, sehingga dirasa kurang terampil dalam penggunaan layanan ini, diasumsikan sebagai penyebab seseorang tidak berniat untuk menggunakannya.

2. Faktor Intention to Use berpengaruh kuat terhadap User's Behavior, sementara Intention to Use dipengaruhi kuat oleh Trust. Perceived security berpengaruh terhadap Trust. Dan Ease of Use berpengaruh terhadap Usefulness.

3. Menurut pengamatan hasil pengukuran kesesuaian model, memperlihatkan model pengembangan IMMPA yang diusulkan dari penelitian ini dirasa lebih baik dari model IMMPA sebelumnya yang diuji oleh Di Pietro et al. (2015) [13] terutama pada nilai probability yang didapatkan sudah mencapai nilai cut of value. Meskipun dari jumlah sampel yang diteliti Di Pietro et al. (2015) [13] sebesar 200 lebih banyak daripada penelitian ini. Menurut pengamatan nilai pengukuran kesesuaian model yang lainnya, seperti RMSEA, CFI, TLI, dan CMIN/DF sudah lebih baik dan secara signifikan fit, sehingga kedepannya dapat diperdebatkan sebagai kerangka konseptual memperluas pengetahuan tentang aspek kognitif, afektif dan perilaku terhadap bidang studi mobile payment. Namun model ini juga tidak boleh dianggap cukup tetapi lebih sebagai kerangka kerja konseptual yang masih perlu dikembangkan kedepan agar tetap relevan untuk konteks di mana keunggulan layanan dan dampak teknologi saling berinteraksi untuk meningkatkan kinerja perusahaan dalam hal kualitas layanan dan kepuasan pengguna.

Saran untuk penelitian berikutnya tentang adopsi mobile payment masih perlu dilakukan terutama pada sampel yang lebih luas, atau berfokus pada lintas generasi pengguna teknologi. Tentunya dengan pengumpulan data yang lebih banyak, hasilnya akan lebih menggambarkan secara general penggunaan mobile payment di Indonesia. 


\section{UCAPAN TERIMA KASIH}

Penulis mengucapkan terima kasih kepada pembimbing 1 Dr. Wing Wahyu Winaro, MAFIS, Ak, atas arahan dan bimbingannya selama proses penyusunan penelitian ini dan terima kasih kepada Jurusan Teknik Informatika, Fakultas Teknologi Industri Universitas Islam Indonesia Yogyakarta atas bantuan dan kinerjanya dalam mendukung penulis.

\section{REFERENCES}

[1] L. Da Chen, "A model of consumer acceptance of mobile payment," Int. J. Mob. Commun., vol. 6, no. 1, pp. 32-52, 2008.

[2] S. G. Dewan and L. Chen, "Mobile Payment Adoption in the US: A Cross-industry, Crossplatform Solution," J. Inf. Priv. Secur., vol. 1, no. 2, pp. 4-28, 2005.

[3] M. Cocosila and H. Trabelsi, "An integrated value-risk investigation of contactless mobile payments adoption," Electron. Commer. Res. Appl., vol. 20, pp. 159-170, 2016.

[4] T. Segara, "Siaran Pers," 2014

[5] PwC Report, "It's time for a consumer-centred metric: introducing 'return on experience,"” Glob. Consum. Insights Surv., 2019.

[6] Z. Hu, S. Ding, S. Li, L. Chen, and S. Yang, "Adoption intention of fintech services for bank users: An empirical examination with an extended technology acceptance model," Symmetry (Basel)., vol. 11, no. 3, 2019.

[7] P. G. Schierz, O. Schilke, and B. W. Wirtz, "Understanding consumer acceptance of mobile payment services: An empirical analysis," Electron. Commer. Res. Appl., vol. 9, no. 3, pp. 209-216, 2010.

[8] T. Zhou, "An empirical examination of continuance intention of mobile payment services," Decis. Support Syst., vol. 54 no. 2, pp. 1085-1091, 2013.

[9] D. L. Amoroso and R. Magnier-Watanabe, "Building a Research Model for Mobile Wallet Consumer Adoption: The Case of Mobile Suica in Japan," J. Theor. Appl. Electron. Commer. Res., vol. 7, no. 1, pp. 13-14, 2012.

[10] C. Kim, M. Mirusmonov, and I. Lee, "An empirical examination of factors influencing the intention to use mobile payment," Comput. Human Behav., vol. 26, no. 3, pp. 310-322, 2010.

[11] Y. Kim, J. Choi, Y. J. Park, and J. Yeon, “The adoption of mobile payment services for 'fintech,"” Int. J. Appl. Eng. Res. vol. 11, no. 2, pp. 1058-1061, 2016.

[12] I. Ajzen, "From intentions to actions: A theory of planned behavior," Action Control, vol. 3, pp. 11-39, 1985.

[13] L. Di Pietro, R. Guglielmetti Mugion, G. Mattia, M. F. Renzi, and M. Toni, "The Integrated Model on Mobile Payment Acceptance (IMMPA): An empirical application to public transport,” Transp. Res. Part C Emerg. Technol., vol. 56, pp. 463-479, 2015.

[14] H. Karjaluoto, M. Mattila, and T. Pento, "Factors underlying attitude formation towards online banking in Finland," Int. J. Bank Mark., vol. 20, no. 6, pp. 261-272, 2002.

[15] A. Bhuwaneswary, "Perilaku Belanja Online Dan Kontrol Diri Mahasiswa," Perilaku Belanja Online Dan Kontrol Diri Mhs. Belitung Di Yogyakarta Tahun 2016, vol. 9, pp. 222-234, 2016.

[16] F. J. Davis, "A Technology Acceptance Model For Empirically Testing New End-User Information Systems: Theory And Results," Management, no. 3652, pp. 1-291, 1985.

[17] E. Rogers, Diffusion of innovation. New York: Free Press, 1995.

[18] V. Venkatesh, M. G. Morris, G. B. Davis, and F. D. Davis, "User Acceptance Of Information Technology: Toward A Unified View," vol. 27, no. 3, pp. 425-478, 2003.

[19] J. Fan, M. Shaou, Y. Li, and X. Huang, "Industrial Management \& Data Systems Article information : Understanding users' attitude toward mobile payment use : a comparative study," p. 19, 2017.

[20] C. Kim, W. Tao, N. Shin, and K. S. Kim, "An empirical study of customers' perceptions of security and trust in e-payment systems," Electron. Commer. Res. Appl., vol. 9, no. 1, pp. 84-95, 2010.

[21] C. C. S. M. Phonthanukitithaworn, An investigation of mobile payment (m-payment) services in Thailand, vol. 8, no. 1. 2016.

[22] A. Y. L. Chong, F. T. S. Chan, and K. B. Ooi, "Predicting consumer decisions to adopt mobile commerce: Cross country empirical examination between China and Malaysia," Decis. Support Syst., vol. 53, no. 1, pp. 34-43, 2012.

[23] J. F. Hair, R. E. Anderson, R. L. Tatham, and W. C. Black, Multivariate Data Analysis, 5th international ed. New Jersey: Prentice- Hall, Inc, 1998.

[24] F. Liébana-Cabanillas, J. Sánchez-Fernández, and F. Muñoz-Leiva, "Antecedents of the adoption of the new mobile payment systems: The moderating effect of age," Comput. Human Behav., vol. 35, pp. 464-478, 2014.

[25] E. Slade, M. Williams, Y. Dwivedi, and N. Piercy, "Exploring consumer adoption of proximity mobile payments," $J$. Strateg. Mark., vol. 23, no. 3, pp. 209-223, 2015.

[26] G. C. Moore and I. Benbasat, "Development of an instrument to measure the perceptions of adopting an information technology innovation," Inf. Syst. Res., vol. 2, no. 3, pp. 192-222, 1991.

[27] F. Calisir, C. Altin Gumussoy, and A. Bayram, "Predicting the behavioral intention to use enterprise resource planning systems: An exploratory extension of the technology acceptance model," Manag. Res. News, vol. 32, no. 7, pp. 597-613, 2009. 